\title{
Lower Ordovician Siphonia cylindrica Eichwald, 1840 from north-western Russia: a pseudo-sponge and a natural 'recorder' of geological history
}

\author{
Petr V. Fedorov
}

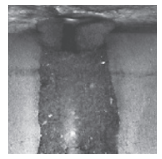

\begin{abstract}
The composition, structure and texture of hard, pebble-sized mineral bodies resembling rounded cylinders with a through-going axial cavity, ascribed by Eichwald (1840) to fossil Porifera under the name Siphonia cylindrica, have been re-examined. The objects can be found at two sites in the vicinity of St. Petersburg (north-western Russia), where they are located at the base of a weakly cemented glauconitic sandstone of the Leetse Formation (Lower Ordovician, Floian). Specimens of S. cylindrica from the collection of Eichwald and a new collection gathered by the author were imaged using scanning electron microscopy (SEM) imaging, energy-dispersive X-ray microanalysis (EDX), and X-ray microtomography (micro-CT). The new data negate previous erroneous assumptions about the siliceous sponge nature of these bodies and suggest that these are phosphorite pseudofossils of nodular genesis. Host rock composition and condition, as well as the main features of the formation and reworking of the nodules, were recorded inside the nodules and only now are available for recovery and discussion. $\bullet$ Key words: pseudo-fossil, phosphorite nodules, Dictyonema Shale, Leetse Formation, NW Russia.
\end{abstract}

Fedorov, P.V. 2018. Lower Ordovician Siphonia cylindrica Eichwald, 1840 from north-western Russia: a pseudosponge and a natural 'recorder' of geological history. Bulletin of Geosciences 93(4), 463-476 (5 figures). Czech Geological Survey, Prague. ISSN 1214-1119. Manuscript received August 26, 2017; accepted in revised form October 1, 2018; published online October 17, 2018; issued December 20, 2018.

Petr V. Fedorov, Institute of Earth Sciences, Saint Petersburg State University, Universitetskaya nab. 7/9, Saint Petersburg, 199034 Russia; p.fedorov@spbu.ru

Hard, pebble-sized, cryptocrystalline, cylindrical mineralized bodies with rounded ends and a through-going axial cavity, occur in the base of glauconitic sandstones of the Lower Ordovician Leetse Formation in the vicinity of St. Petersburg (northwestern Russia). These objects were identified by the $19^{\text {th }}$ century palaeontologist Karl Eduard Eichwald as fossil sponges. In 1840, Eichwald ascribed these bodies to the genus Siphonia Goldfuss, 1826 and gave them a brief description under the name $S$. cylindrica. Later, Eichwald significantly enlarged his description of S. cylindrica and accompanied the descriptions with what seemed to him to be evidence of their sponge origin.

The attribution of S. cylindrica Eichwald, 1840 both to the genus Siphonia and to Porifera has been questioned repeatedly, however, the authors of the two subsequent revisions (Lamansky 1905, Asatkin 1949), despite the lack of obvious evidence of the sponge nature of the fossil, preferred to use the name given by Eichwald, but in the open nomenclature.

In the course of systematic study of the Lower Ordovician deposits in the vicinity of St. Petersburg, the author noticed that the stratigraphic level bearing S. cylindrica is the same as the level with sandy phosphorite concretions described in the Tosna and Sablinka river valleys (Ershova et al. 2006). Dark brown cryptocrystalline cement of the sandy phosphorite concretions looks completely identical to the mineral substance composing the bodies of $S$. cylindrica. Moreover, on the surface of several specimens of S. cylindrica thin transverse encircling grooves, unusual for sponges were detected. These features were not reported in the descriptions of the $19^{\text {th }}$ and $20^{\text {th }}$ centuries. Therefore, the author undertook a new study of S. cylindrica from the collection of Eichwald and his personal collection; the results are given below.

Review of Cretaceous sponges, which were also called 'Siphonia cylindrica' in the first half of the $19^{\text {th }}$ century, is beyond the scope of this article. Information about these sponges may be found in the publications by Sollas (1877) and Zittel (1878). The authorship and history of the study of the genus Siphonia are not discussed.

\section{Geological background}

Ordovician deposits can be found in many outcrops in the vicinity of St. Petersburg (Fig. 1A). The Ordovician strata 

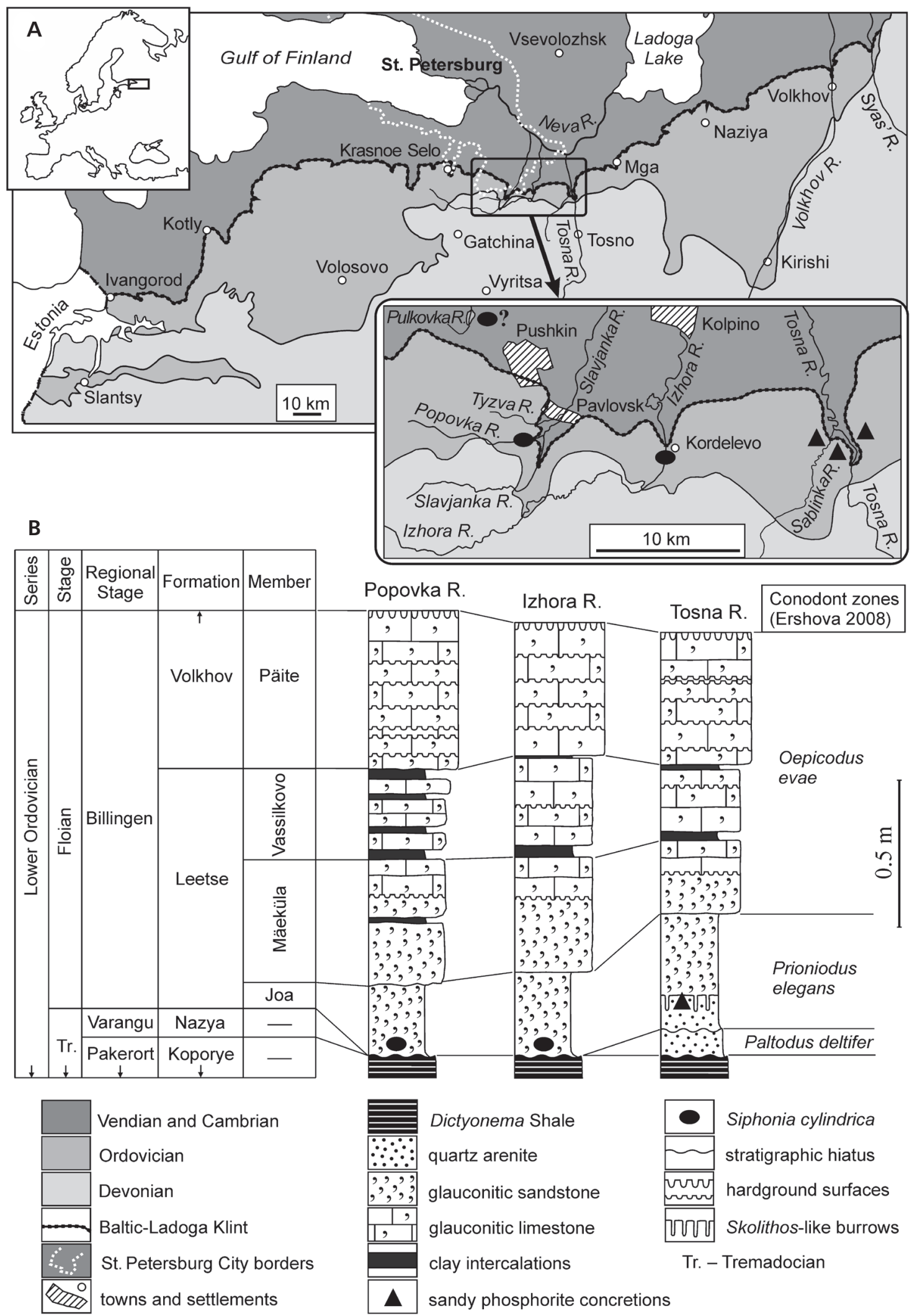

Figure 1. Geographic and stratigraphic distribution of Siphonia cylindrica Eichwald, 1840 in north-western Russia. - A - schematic geological map of the Saint Petersburg area with inset map of Siphonia cylindrica localities. Modified after Sokolova (1971). B - a correlation scheme for the sections of the Lower Ordovician containing Siphonia cylindrica and neighboring sections bearing sandy phosphorite concretions. 
comprise mostly limestone and secondary dolomite, which are the most resistant local rock types. The carbonate rocks form the so-called 'Ordovician Plateau' and can usually be found slightly elevated above the surrounding landscape. Ordovician rocks dip at a very low angle (about $2 \mathrm{~m} / \mathrm{km}$ ) to the S or SE (Zander \& Salomon 1971). The Cenozoic erosional escarpment, known as the Baltic-Ladoga Klint exposes the Ordovician strata to the north. The plain north of the Baltic-Ladoga Klint is composed of Terreneuvian clay, while the base of the Klint consists of middle-upper Cambrian quartz arenite. The Palaeozoic deposits as well as the Baltic-Ladoga Klint can be followed to the west into northern Estonia. Outcrops of Cambrian and Ordovician rocks are located in the valleys of numerous rivers and creeks flowing from the Ordovician Plateau in a northerly direction, and in a few quarries.

Lower to lower Middle Ordovician deposits in the vicinity of St. Petersburg are subdivided into five formations (e.g. Popov et al. 1989, Suyarkova \& Koren' 2009), which are: the uppermost Cambrian to lower Tremadocian Tosna Formation (Obolus Sandstone), the lower Tremadocian Koporye Formation (bituminous graptolitic argillite, Dictyonema Shale), the upper Tremadocian to middle Floian Leetse Formation (glauconitic sandstone and limestone), and the middle Floian to lower Darriwilian Volkhov Formation (glauconitic limestone). East of St. Petersburg, between the Tosna River and the Rechka Creek, a 5-20 cm layer of sandstone, the middle Tremadocian Nazya Formation (Paltodus deltifer conodont Zone), unconformably overlies the Koporye Formation and is overlaid by the Leetse Formation (Popov et al. 1989). The total thickness of formations listed above does not exceed $12 \mathrm{~m}$. The relative ages of the Lower to Middle Ordovician rock strata in the vicinity of St. Petersburg are usually determined using conodonts (e.g. Popov et al. 1989, Tolmacheva 2001, Tolmacheva et al. 2001).

Four regional stages have been recognized for the Lower Ordovician succession of eastern Baltoscandia (e.g. Suyarkova \& Koren' 2009): the Pakerort Regional Stage (uppermost Cambrian and lower Tremadocian) comprises the Tosna and the Koporye formations; the Varangu Regional Stage comprises the Nazya Formation; the Hunneberg Regional Stage (upper Tremadocian and lower Floian) together with the Billingen Regional Stage (lower to upper Floian) comprise the Leetse Formation as well as the lowermost beds of the glauconitic limestone of the Volkhov Formation.

The Leetse Formation consists of glauconitic and quartz-glauconitic sandstone and siltstone, with layers of quartz- or glauconitic-quartz sandstone at the base, and locally, intercalated layers of clay. The lowermost sandstone is clayey and weakly cemented, whereas the upper layers have stronger limestone cementation. The sandy glauconitic rocks are overlain by green or multi- colored, laminated, glauconitic limestone with interlayers of clay. The Leetse Formation unconformably overlies the Koporye and the Nazya formations and is overlain by a medium-bedded, glauconitic limestone of the Päite Member that is also informally called the 'Lower Dikary Member' (lower Volkhov Formation, uppermost Floian). The Leetse Formation comprises three standard Baltoscandian conodont zones, from bottom to top: $\mathrm{Pa}$ roistodus proteus, Prioniodus elegans, and Oepikodus evae (Tolmacheva 2001). The thickness of the Leetse Formation in the vicinity of St. Petersburg varies from about 0.5 to $2.7 \mathrm{~m}$ and progressively decreases in a southsoutheasterly direction. The age of the basal layers of the Leetse Formation also decreases in the same direction (Ershova 2008).

All the mentioned rocks were formed in the epeiric Baltoscandian palaeobasin that covered significant parts of the East European Craton during the late Vendian-Early Palaeozoic (e.g. Nikishin et al. 1996, Sliaupa et al. 2006).

Dictyonema Shale of the Koporye Formation is considered as the eastern transgressive tongue of the uppermost unit of the Alum Shale Formation (Nielsen $\&$ Schovsbo 2007). Western facies analogs of the Nazya sandstone are the clay of the Varangu Formation in Estonia (Heinsalu \& Bednarczyk 1997) and carbonates, shales, and glauconitic beds of Bjørkåsholmen Formation (formerly termed 'Ceratopyge Limestone') in Norway and Sweden (Egenhoff et al. 2010). Glauconitic sandstone of the Leetse Formation and glauconitic limestone of the Volkhov Formation were deposited simultaneously with red and gray bioclastic limestones on the island Öland and in western and middle Sweden, and graptolitic shale in the Oslo region, Norway, and on the island Bornholm, Denmark (Männil 1966).

\section{Study history of Siphonia cylindrica}

Eichwald (1840) gave very little information in his first description of S. cylindrica: 'the body of the sponge ('Polypenstock' in original text) is similar in general shape to $S$. conoidea Goldfuss, but slightly smaller; it is absolutely smooth from the outside; a cavity that is slightly wider on the top than the bottom extends from its top to base through the central part; neither parenchyma, nor pores, nor fibers to be seen on the body surface; the sponges are found in Popovka and Pulkovka rivers as pebbles' (Eichwald 1840, pp. 209, 210).

The most thorough description of $S$. cylindrica was given by Eichwald in his monograph 'Lethaea Rossica', where he for the first time indicated the size and color of the fossil, reported conical opening of the apertures of the axial cavity and the presence of additional blind canals on the surfaces of some specimens (Eichwald 1860, 
pp. 329-331, 1859, pl. 22, figs 12a-e). Eichwald described the color of the fossil as 'dark', but noted that the outer surface and the surface of the axial cavity are noticeably lighter. He interpreted the dark color as resulting from impregnation of mineral matter in bitumen. Also, he explained the formation of the blind canals penetrating the wall of some specimens by the activity of boring sponges.

Eichwald presented three arguments in favor of his attribution of $S$. cylindrica to the Porifera in several sentences. The arguments are deemed as very strange in our current day: 1) 'If the polyp (fossil sponge - P.F.) is rubbed against another stone it produces an empyreumatic odor similar to that of sponges burned; it proves the nature of sponge-like body fossil.' [Le polypier frotte contre une autre pierre, répand une odour empyreumatique, semblable à celle des éponges brulées; cela prouve la nature spongieuse de ce corps fossile.] (Eichwald 1860, pp. 329, 330); 2) 'Its structure appears fibrous, very thin fibers travel through the polyp in all directions but are so little distinct that we can hardly recognize them.' [Sa structure parait fibreuse; de très-minces fibres parcourent le polypier dans toutes les directions, mais sont si peu distinctes, que l'on peut a peine les reconnaitre.] (Eichwald 1860, p. 330); 3) 'Some polyps are very regular in one end, while on the other the top of a wide central cavity is cut obliquely, and therefore, it is absolutely uneven: the indeterminate form proves that these bodies are fossilized sponges, and not artificial bodies, as is sometimes assumed.' [Dans quelques polypiers une extrémité est très-régulière, tandis qu'à l'autre, le sommet a large cavité centrale, est come coupé obliquement, et par conséquent tout-a-fait irregulier: c'est précisément cette forme indéterminé qui prouve que ces corps sont des éponges fossiles, et non pas des corps artificiels, come on l'a quelquefois suppose.] (Eichwald 1860, p. 330).

It follows from Eichwald's remarks in the 'Lethaea Rossica', that not all his contemporaries trusted his classification of $S$. cylindrica as a fossil. This was probably due to the fact that palaeontologists of that time were already aware of features of the internal structure of fossilized sponges and about distribution of sponges of the genus Siphonia exclusively in the Cretaceous-Neogene deposits. In particular, Sollas characterized the description of S. cylindrica, given by Eichwald in 'Lethaea Rossica', as not containing sufficient arguments for reference of these objects to the sponges, as a whole, and definitely lacking evidence that it is a Siphonia (Sollas 1877, p. 802).

Lamansky (1905) performed a re-description of S. cylindrica to which he added information about the number and direction of additional blind canals penetrating the walls of the fossils and about the microstructure of its constituent minerals. He counted two to ten blind canals, which are cylindrical recesses oriented parallel or at an angle to the lateral walls. The presence of too many additional canals leads, according Lamansky (1905), to the loss of the right cylindrical shape of fossil bodies and the appearance of appendages and protrusions.

Lamansky described homogeneous mineral matter of the fossil as the amorphous siliceous substance, which sometimes contains small crystals of pyrite. He outlined his doubts about attribution of the studied objects to the genus Siphonia by a question mark after the generic name. However, he continued to believe that S.? cylindrica most probably belonged to the sponges.

Asatkin (1949) conditionally placed S.? cylindrica in the subgroup Tetracladina, order Demospongia, but noted that the assignment of this form to the Siphonia in particular, and to the sponges in general, remains in question. He observed not only the typical cylindrical S.? cylindrica but also samples of narrower, elongated, sometimes slightly curved objects, and samples whose shape was close to spherical. Asatkin also drew attention to the fact that no traces of attachment of the supposed sponges to substrate exist.

Figure 2. Specimens of Siphonia cylindrica Eichwald, 1840 stored in the Paleontological-Stratigraphical Museum of Saint Petersburg State University. A-S - specimens from the Eichwald's collection; A - incomplete specimen broken along the axial cavity, number 1/344; B-E - specimen bearing encircling grooves and blind canals, number 1/345: side view with two blind canals oriented parallel and perpendicular to axial cavity (B), another side view with two clearly discernible parallel encircling grooves (C), view from the narrower aperture of the axial cavity (D), view from the wider aperture of the axial cavity $(\mathrm{E}) ; \mathrm{F}-\mathrm{H}$ - short toroidal specimen, number 1/1367: view from the narrower aperture $(\mathrm{F})$, side view $(\mathrm{G})$, view from the wider aperture $(\mathrm{H})$; I-L - elongated specimen with oblique end, number 1/1368: side view, oblique edge is facing the observer (I), view from the wider aperture (J), view from the narrower aperture $(\mathrm{K})$; side view, the oblique edge deviates left $(\mathrm{L})$; $\mathrm{M}-\mathrm{P}$ - the largest asymmetrical cracked specimen with protrusions and blind canals, number 1/1369: view from the wider aperture $(\mathrm{M})$, view from the wider side $(\mathrm{N})$, view from the narrower aperture $(\mathrm{O})$, view from the narrower side (P); Q-S - incomplete specimen broken perpendicular to axial cavity, number 1/1373: view from the aperture side where the aperture has the appearance of a collar surrounding the pit $(\mathrm{Q})$, view from the side bearing encircling groove (R), view of broken surface (S). $\bullet$ T-AI specimens from the author's collection; T-W - another elongated specimen with oblique end, number 411/2: view from the wider aperture (T), side view: the oblique end is facing right $(\mathrm{U})$; side view: the oblique end is turned from the observer and to the left $(\mathrm{V})$, view from the narrower aperture (W); $\mathrm{X}, \mathrm{Y}$ - damaged specimen with smooth fracture surface situated normal to the axial cavity, number 411/3: side view (X), view from the broken end (Y); Z-AC - incomplete specimen broken perpendicular to the axial cavity, number 411/4: flat fracture surface (Z), aperture view (AA), side view with the encircling groove $(\mathrm{AB})$. Note protrusion with merged blind canals on the right; (ac) another side with the encircling groove and blind canals; $\mathrm{AD}$, $\mathrm{AE}$ heavily fractured specimen that disintegrated along the fissures during a subsequent study, number 411/5: side view (AD), view from wider aperture (AE); $\mathrm{AF}-\mathrm{AI}$ - asymmetrical specimen with protrusion, number 411/6: side view from the wider side (AF), view from the narrower aperture (AG), view from the wider aperture $(\mathrm{AH})$, side view from the narrower side $(\mathrm{AI})$. Scale bar $=1 \mathrm{~cm}$. 
Petr V. Fedorov • Lower Ordovician Siphonia cylindrica Eichwald, 1840 from north-western Russia
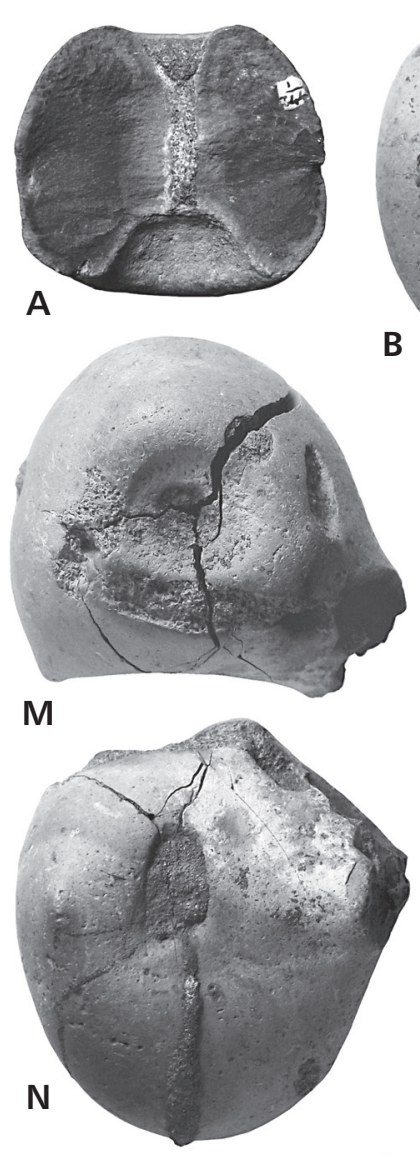

D
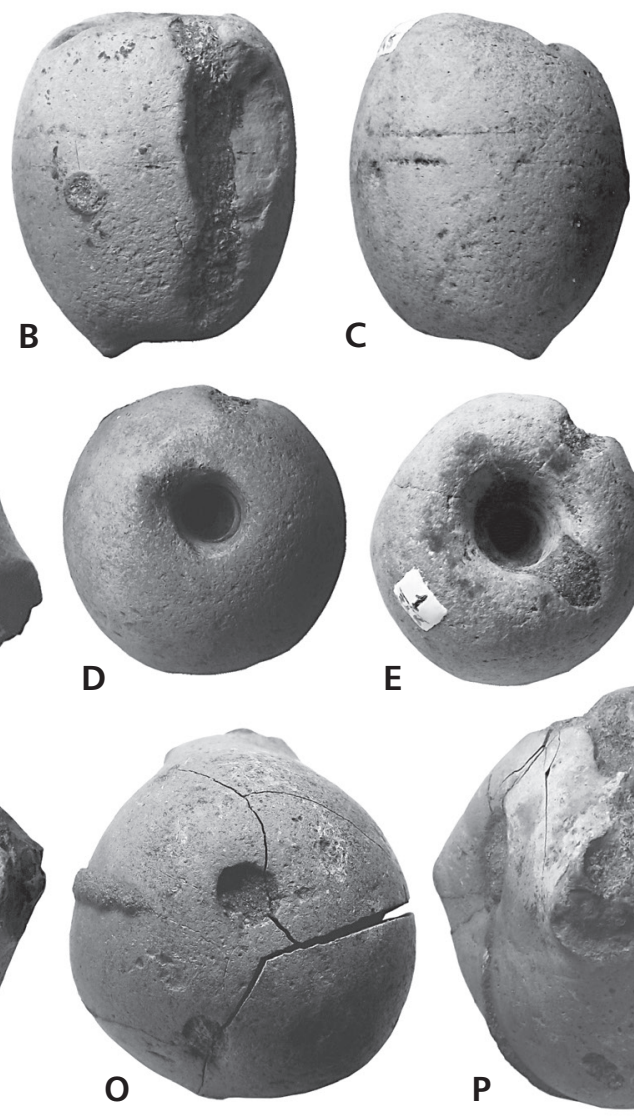

G
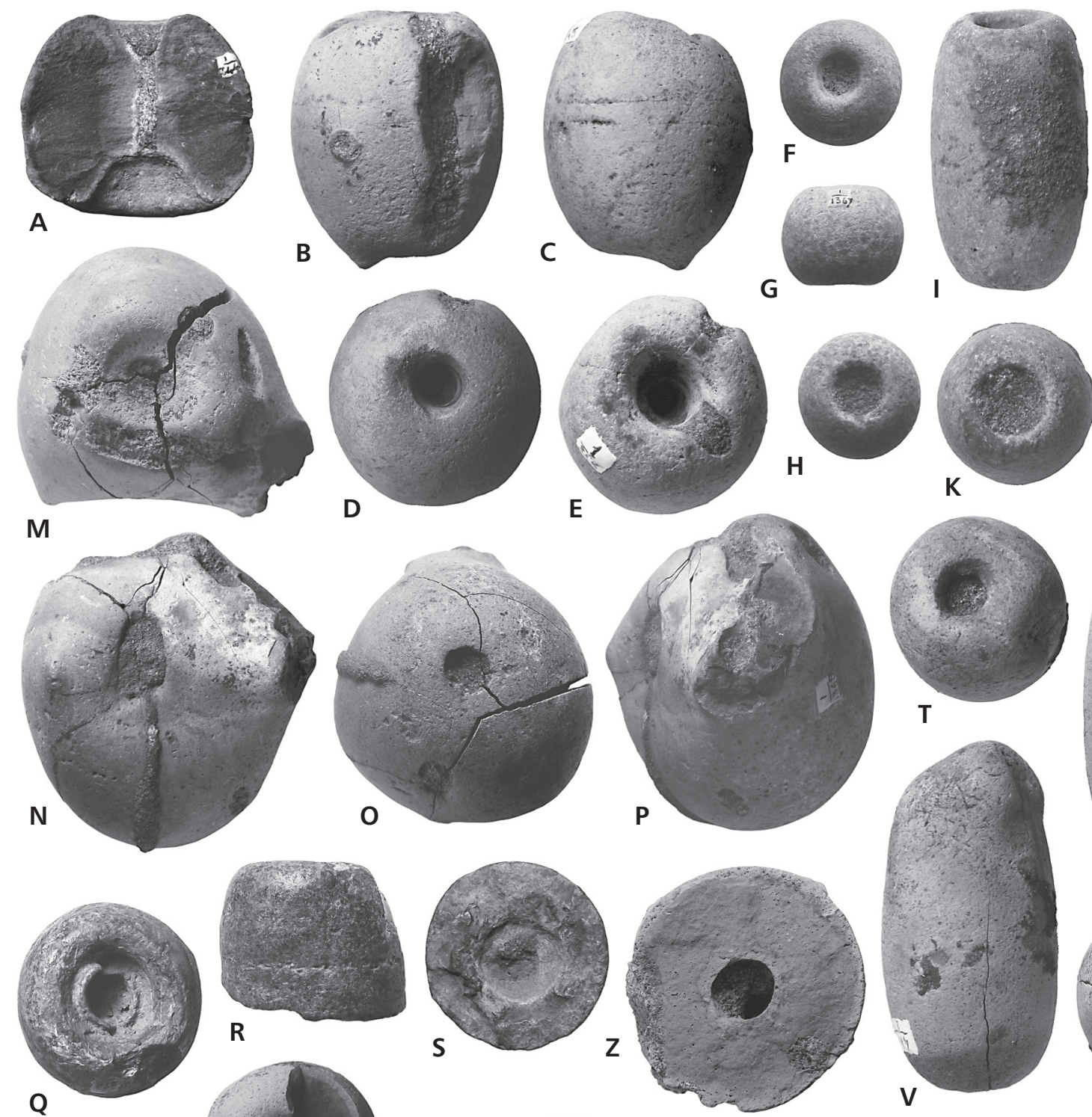

$\mathbf{R}$
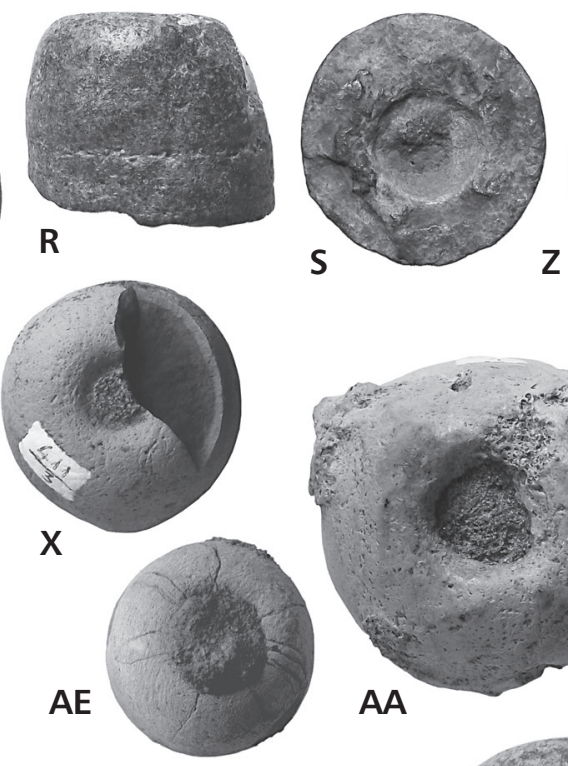

S
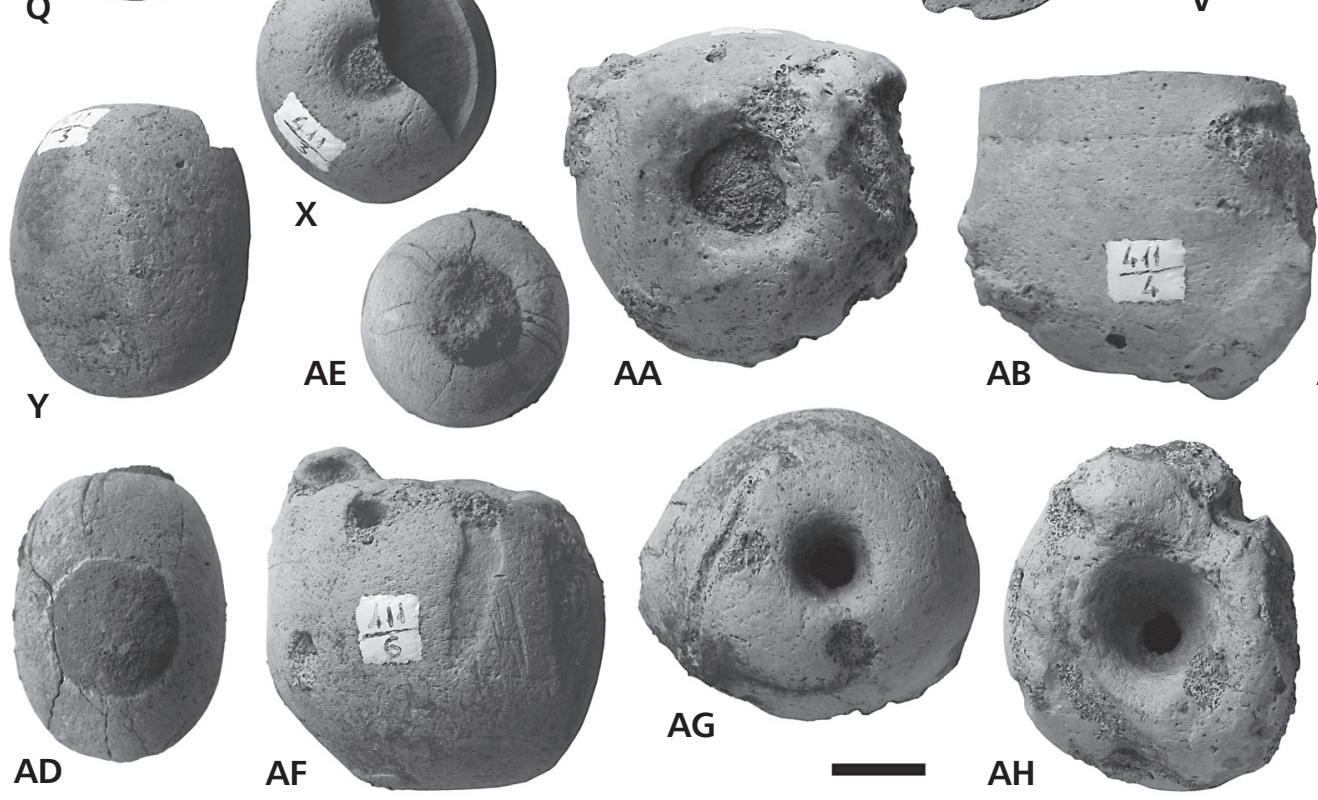

AA
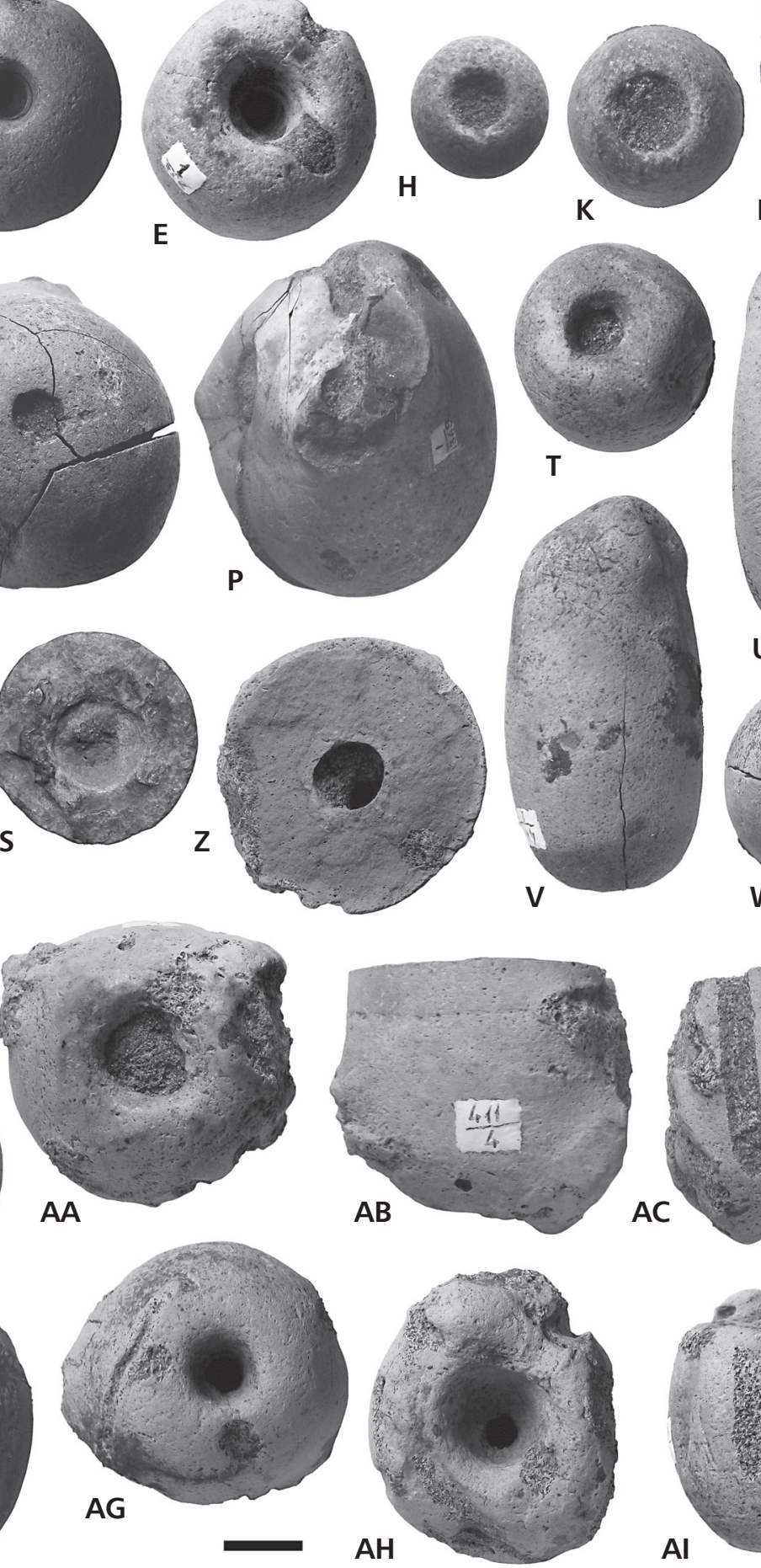
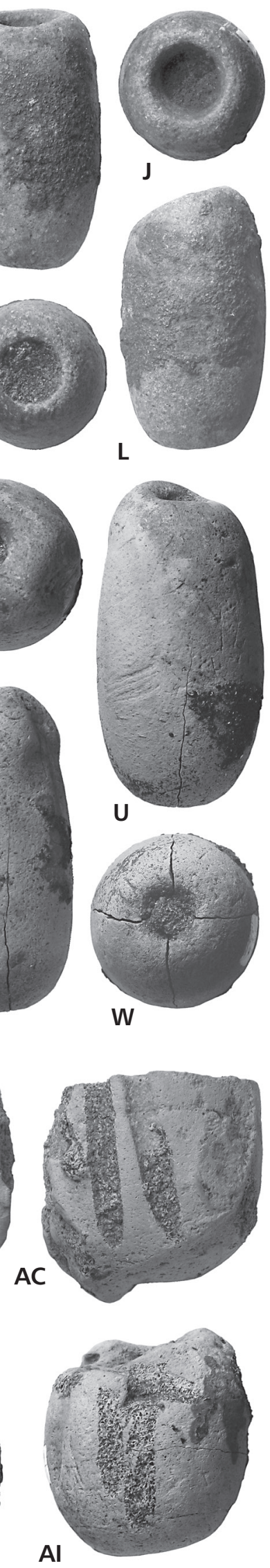
Folowing the work of Asatkin, only four authors (Alichova 1953, Rõõmusoks 1960, Selivanova 1971, Rhebergen 2012) noted the sponge S. cylindrica from the Leetse Formation in their works.

\section{Geographic and stratigraphic distribution of Siphonia cylindrica}

The author's field observations revealed that the geographical distribution of S. cylindrica in the vicinity of St. Petersburg is limited to two areas located near the town of Pushkin at the intersection of the Baltic-Ladoga Klint by the valleys of the rivers Izhora and Popovka (Fig. 1A, B). The assertion of Eichwald (1840) on the presence of $S$. cylindrica in the valley of the Pulkovka River north-west of the Pushkin Town could not be verified. Outcrops on the Pulkovka River nowadays are flooded by a reservoir and therefore should be considered as lost.

Siphonia cylindrica is very rare in the modern outcrops at the Popovka and Izhora rivers. All new samples were collected, like the previous ones, at the base of the glauconitic sandstone of the Leetse Formation. The study of conodonts reveals that the base of glauconitic sandstone on the Popovka and Izhora rivers belongs to the conodont zone Prioniodus elegans (Ershova 2008).

Samples of S. cylindrica are also known from localities in Northern Estonia (Rõõmusoks 1960, Rhebergen 2012), in particular from Mäeküla (Rhebergen 2012), but their stratigraphic position has not been indicated.

\section{Material and methods}

Material for the present study consists of 15 specimens of S. cylindrica from the collection of Eichwald, and 10 specimens collected by the author at the valleys of the Izhora and Popovka rivers in the period from 1995 to 2010.

Specimens from the collection of Eichwald are stored in the Paleontological-Stratigraphical Museum of St. Petersburg State University under the numbers: 1/344 (Fig. 2A), 1/345 (Fig. 2B-E), 1/347, 1/1362, 1/1364, 1/1365, 1/1366, 1/1367 (Fig. 2F-H), 1/1368 (Fig. 2I-L), 1/1369 (Fig. 2M-P), 1/1370, 1/1371, 1/1372, 1/1373 (Fig. 2Q-S); there is also one specimen with unreadable numbers.

Specimens from the author's collection are stored in the above-mentioned museum under the numbers: $411 / 1$, 411/2 (Fig. 2T-W), 411/3 (Fig. 2X, Y), 411/4 (Fig. 2Z, AA-AC), 411/5 (Fig. 2AD, AE), 411/6 (Fig. 2AF-AI), $411 / 7,411 / 8,411 / 9,411 / 10$. One specimen of these (411/1) was found on the bank of the Popovka River, and the nine others collected in a small sand quarry near the village Kordelevo at the right bank of the Izhora
River: two samples $(411 / 2,411 / 7)$ were found directly in outcrop; the rest at the quarry tailings. The specimens found in outcrop were located immediately above the base of the glauconitic sandstone, at a distance of a few centimetres from each other; their axial cavities were oriented horizontally, parallel to the smooth contact with the underlying Dictyonema Shale.

The specimen 411/8 was found broken into fragments by the cracks oriented along and across the axial cavity. Another specimen (411/5), covered by a dense network of cracks, crumbled into fragments in the process of the study thus only numerous fragments of it are currently represented in the collection number 411 .

Surfaces of the listed specimens, as well as large and small fragments were thoroughly examined under an ordinary binocular microscope. Visible details of the structure on the surface of specimens were photographed using the digital microscope Dino-Lite Pro Digital Microscope AM-413ZTA with a zoom range 20-230 times.

The study of the composition and microstructure of small fragments of the specimens $411 / 8$ and $411 / 5$ was performed at the Center for Microscopy and Microanalysis of Research Park of St. Petersburg State University, Russian Federation. A scanning electron microscope Tabletop TM 3000 (Hitachi) with Swift ED 3000 X-Ray Microanalysis system was used for producing images with magnifications of up to 3000 times; for higher magnifications, the system Quanta 200 3D Dual Beam (FEI Company) in the SEM mode was used. One of the fragments of the specimen 411/8 was enclosed in epoxy resin and polished. Its chemical composition was analyzed

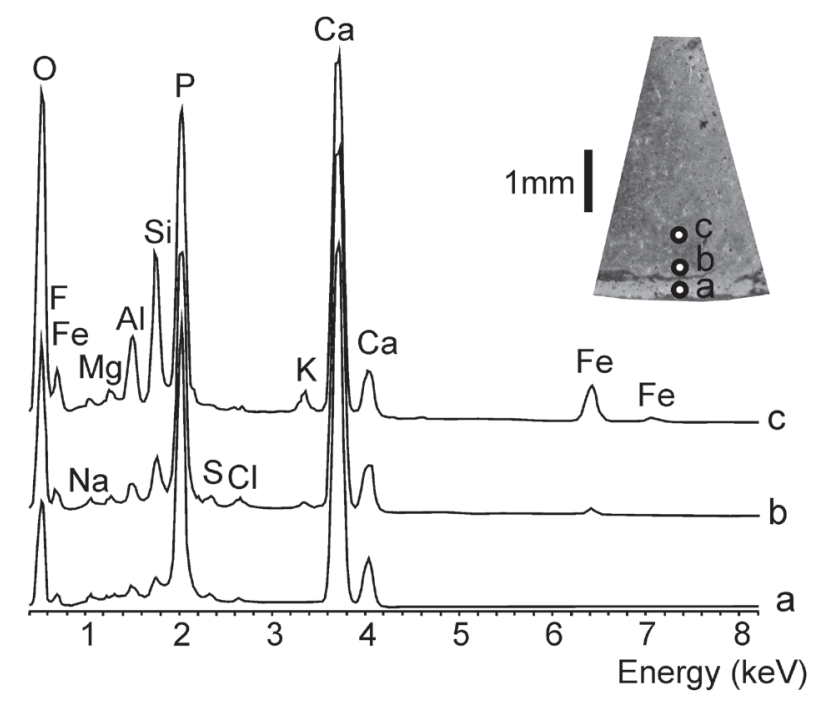

Figure 3. EDS spectra of transverse section of Siphonia cylindrica. Abbreviations: a - bleached outer layer; $\mathrm{b}-$ depth of $0.5 \mathrm{~mm}$; $\mathrm{c}-$ depth of $1.1 \mathrm{~mm}$. Small fragment of specimen number $411 / 8$. 

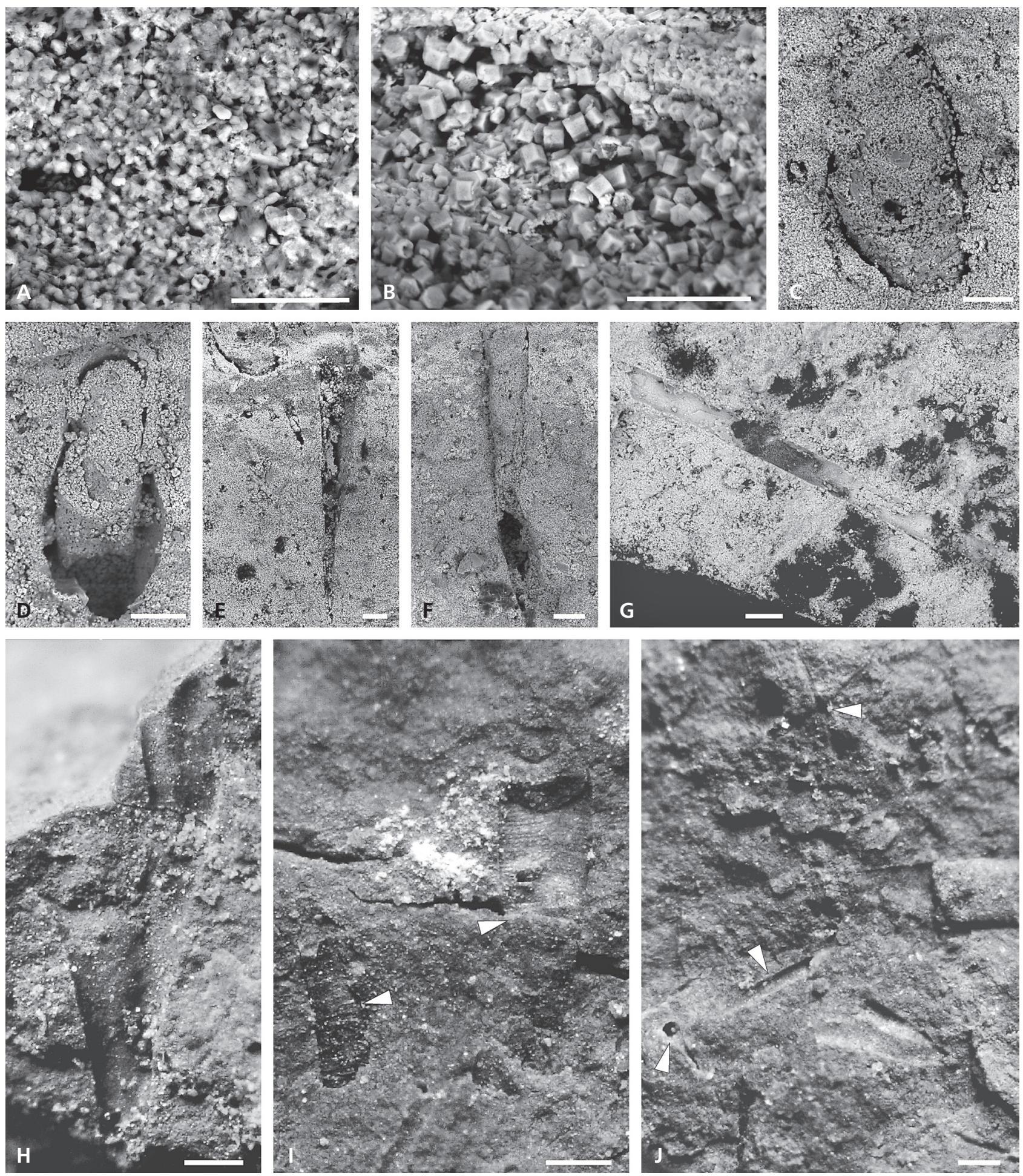

Figure 4. Texture of mineral substance of Siphonia cylindrica and organic remains found on the surface of the fragments. $\bullet$ A-G - SEM imaging. Specimen number 411/8; A - the predominant texture consisting of apatite microcrystals, some pores between them contain fine blades of illite; B - void of indefinite shape lined with euhedral crystals of apatite; C - part of inner core of dendroid graptolite theca; D - oblique cross section of dendroid graptolite theca with the void instead of organic skeleton; E - oblique cross section of theca (top left), and void on graptolite sicula (right of centre); F - unidentified part of a graptolite colony; $\mathrm{G}$ - mold of diactine spicule. $\bullet \mathrm{H}-\mathrm{J}$ - digital microscope photos. Specimen number 411/5; $\mathrm{H}$ - part of the branch of dendroid graptolite with smooth cortical layer; I - two graptolite thecae (arrowed) with fusellar layer; J - molds on hexactine spicules (arrowed) together with fragments of graptolites. Scale bars: $A=20 \mu \mathrm{m} ; \mathrm{B}-\mathrm{G}=40 \mu \mathrm{m} ; \mathrm{H}-\mathrm{J}=200 \mu \mathrm{m}$. 
by the X-Ray Microanalysis system from the outer light beige colored layer to a depth, where the mineral mass becomes dark brown.

The visual examination revealed one to three thin encircling grooves arranged perpendicularly to the axial cavities of S. cylindrica on the surfaces of four of the twenty five specimens (Fig. 2B, C, R, AB, AC, AF, AI). Three specimens $(1 / 345,1 / 1373,411 / 6)$ with encircling grooves were studied by X-ray microtomography using tomograph Skyscan 1172 (Bruker Corporation) at the Centre for GeoEnvironmental Research and Modelling (GEOMODEL) in the Research Park of the St. Petersburg State University, Russian Federation. The SkyScan 1172 settings were as follows: $\mathrm{Cu}$ radiation, acceleration voltage $100 \mathrm{kV}$, copper and aluminum filters, resolution $13.79 \mu \mathrm{m}$, sample rotation angle -0.2 grad., 3 scans in one position, exposure $-20.2 \mathrm{sec}$. For reconstruction of the shadow image array, an NRecon software package (Bruker-MicroCT) was used, because it is capable of neutralizing the instrumental artefacts and can provide a gray scale shades corresponding to X-ray absorption, and, consequently, to chemical composition of the sample. Microtomographic sections obtained were analyzed using DataViewer and CTVox (BrukerMicroCT) software packages.

\section{Results of the study of Siphonia cylindrica}

\section{Composition}

Microprobe analysis revealed that the bodies of $S$. cylindrica are composed of fluorapatite with a variable admixture of silicates and iron compounds, i.e. they are ordinary phosphorite (Fig. 3). The bleached phosphorite layer near the nodule surface is devoid of iron and depleted in silica, aluminum, and magnesium (Fig. 3).

\section{Texture}

No fibrous texture has been observed in the examined S. cylindrica fragments. Scanning Electron Microscope observations showed that the mineral substance of $S$. cylindrica is represented mainly by randomly oriented short-prismatic crystals of fluorapatite with a size of 0.3-4 microns, united in clusters or, rarely, solitary; irregular pores of micron size are placed between apatite clusters and crystals, some of which are filled with fine blades of illite (Fig. 4A). The form of the apatite crystals ranges from anhedral to euhedral. Single tabular apatite euhedra of larger size (up to 20 microns) are scattered in the matrix of small crystals, as are microscopic voids that may be divided into biomorphic and indefinitely shaped.
These voids are well distinguishable only on the chips of S. cylindrica, oriented perpendicular or slightly inclined to the axial cavity.

The voids of indefinite shape are visible on the surfaces of the chips as small elongated indentations with a size of 25-100 microns and with no similarity with recognizable organic remains. Inside, they are lined with euhedral crystals of apatite sized 1-12 microns (Fig. 4B).

The biomorphic voids occupy the space that was formerly filled with fossils: dendroid graptolites and siliceous sponge spicules. The voids formed on graptolite fossils are hollow molds of fragments of uncompressed organic graptolite skeletons bounded by both inner, and outer mineral cores (Fig 4C-F, H-I); their size varies from several tens microns to several millimetres. The walls of some of these voids represent the finest impressions of the external and internal surfaces of dendroid graptolite thecae, with visible microscopic details of the surface relief of the cortical (Fig. 4H) or fuselar (Fig. 4I) layers. The voids formed on the spicules are less common than those of graptolites; they are represented by hollow molds on hexactins and diactins of hexactinellid sponges (Fig. $4 \mathrm{G}, \mathrm{J})$. The walls of these voids are smooth. The molds of graptolite and sponge diactins are oriented perpendicular to the axial cavity of the $S$. cylindrica bodies.

\section{Structure}

Computer aided microtomography of the S. cylindrica samples, bearing encircling grooves, revealed two kinds of macroscopic internal structures in the otherwise homogeneous phosphorite matrix. The first kind consists of thin layers oriented perpendicular or at a very slight angle to the axial cavity (Fig. 5A-L). The thin layers are enriched with a substance, which is distinguished on the tomographic reconstructions by darker color than the enclosing phosphorite matrix. Thin layers also contain randomly disseminated, white colored, isometric and lamellar mineral particles, and voids appearing in the $\mathrm{X}$-ray shadow images as black dots and lenses. The second kind of the internal structures is represented by straight and slightly curved tunnels with diameters of 3-4 mm, filled with sand-sized granular material, identified here as trace fossils (Fig. 5A-C, K, L).

Tomographic reconstructions are based on multiple $\mathrm{X}$-ray shadow projections of the studied objects, therefore elements of the internal structure of the light-colored objects are characterized by maximum absorption of radiation energy while the dark-colored areas have minimal absorption (Cnudde \& Boone 2013). As the absorption of X-ray energy is mainly determined by the density of the substance (e.g. Algeo et al. 1994), in this case the thin layers that show darker shades of gray are 

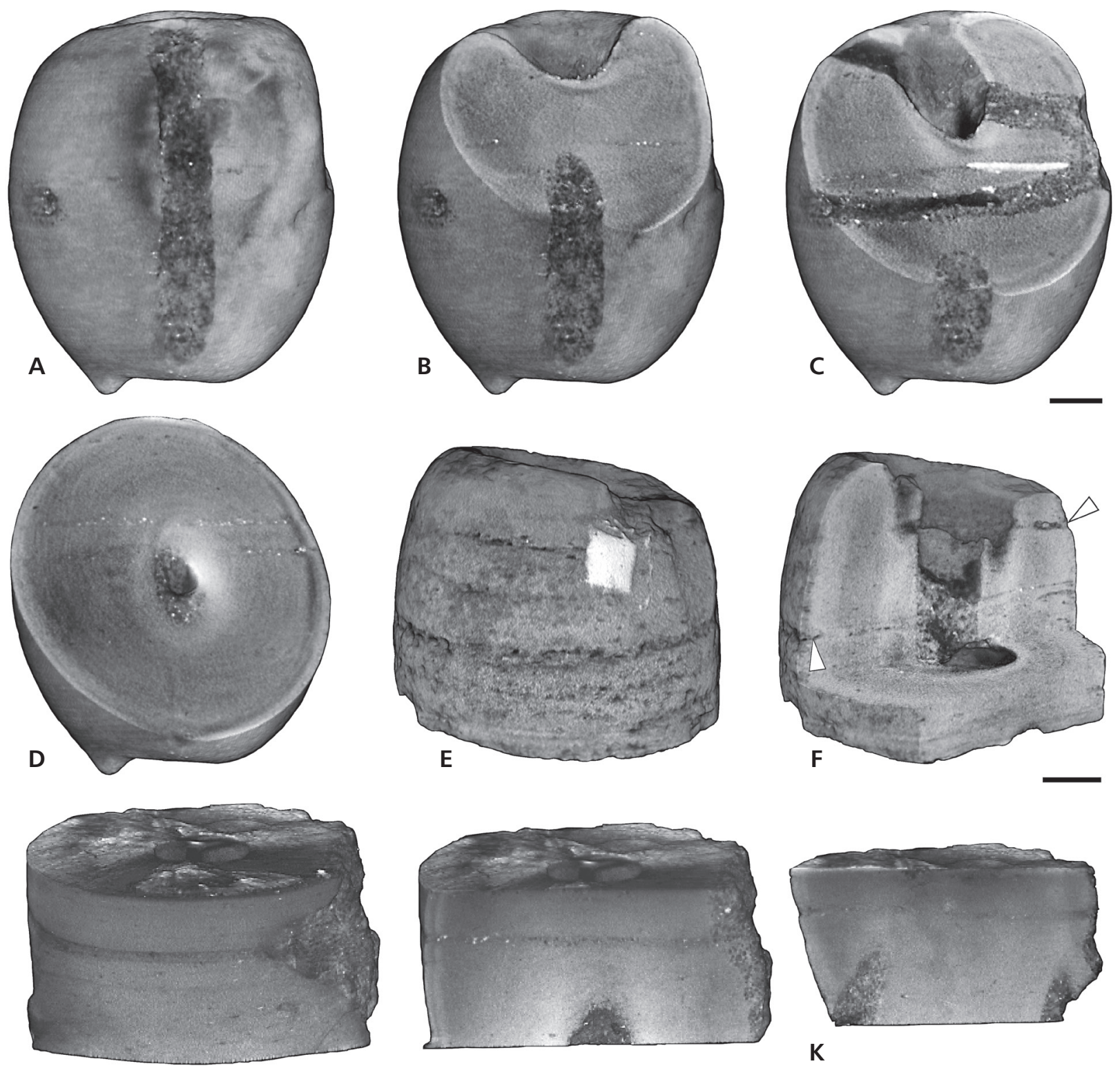

G

I
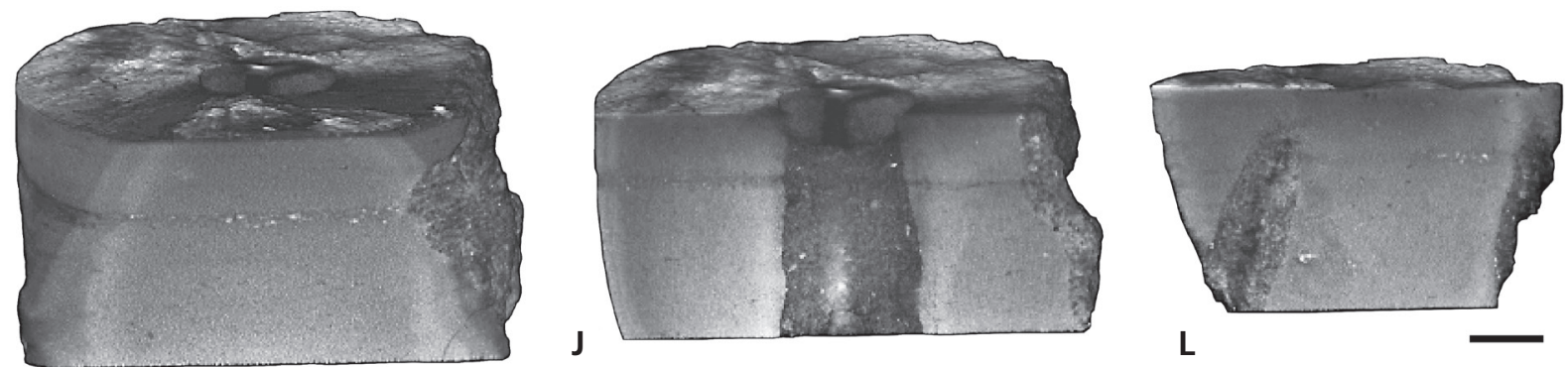

Figure 5. Micro-CT images of three Siphonia cylindrica specimens bearing transverse encircling grooves. 3D reconstructions of surfaces and sections showing the internal stratification and trace fossils within the $S$. cylindrica bodies. • A-D - specimen number 1/345; A - side view; B-D - successive oblique sections showing two thin layers perpendicular to the axial channel, as well as slightly curved trace fossils partly filled by glauconitic sand. The thin layers are marked with an admixture of very fine light material (dark dots) and pyrite (white dots and strip). $\bullet$ E, F - specimen number 1/1373; E - oblique side view; F - stepped section showing the stratified distribution of particles with a density different from that of phosphorite, and thin voids (arrowed) formed during weathering. $\bullet \mathrm{G}-\mathrm{L}$ - reconstructed part of specimen number 411/4; $\mathrm{G}$ - oblique surface view, the filling of the encircling groove is distinctly darker than the containing phosphorite; $\mathrm{H}-\mathrm{L}$ - successive longitudinal sections allowing tracing the thin layer of light material inside the phosphorite body. The last two sections also reveal inclined trace fossils filled with glauconitic sand. Scale bars $=0.5 \mathrm{~cm}$. 
composed of a less dense substance than the enclosing phosphorite, and inclusions of white colored matter on the contrary are denser than phosphorite.

Resolution of the microtomographic reconstructions was insufficient to determine the microstructure and composition of the thin layers. However, we can assume that the layers contain dispersed silt sized mineral grains with densities lower than that of apatite (perhaps quartz), and/or they have small voids. The white colored inclusions are undoubtedly crystals and intergrowths of pyrite, since pyrite is the sole heavy mineral whose presence in a cryptocrystalline substance of $S$. cylindrica was detected by Lamansky (1905) in thin sections.

\section{Discussion}

Both Eichwald's opinion $(1855,1860,1861)$ that the mineral substance of $S$. cylindrica is impregnated with bitumen, and the conclusion of Lamansky (1905) about the siliceous composition of this substance, proved to be erroneous. The current knowledge of the real composition of the mineral bodies allows for a rational explanation for the sharp smell of "burned horn sponge" that occurs during grinding. This smell is a characteristic property of phosphorite, independent of its age, concentration and host rocks (e.g. Ransome \& Gale 1915, p. 378; Girty 1927, p. 208).

Can new finds of the spicule molds of hexactinellid sponges serve as a further argument in favor of the sponge nature of S. cylindrica? Apparently not, because phosphorite composition, internal layering, trace fossils and the presence of graptolites, oriented perpendicularly to the axial cavity (parallel to the thin layers), provide sufficient grounds for the final resolution of the question regarding the nature of the S. cylindrica. In fact, the mineral bodies called by Eichwald ' $S$. cylindrica' are phosphorite nodules of diagenetic origin like the sandy phosphorite concretions located in situ (Ershova et al. 2006) on the same stratigraphic level at the base of neighboring sections of glauconitic sandstone (Fig. 1B). The main difference between the nodules and the sandy concretions is that the phosphorite of the nodules largely replaces a host rock while the phosphorite of the concretions fills the spaces between the grains of the enclosing sandstone, being actually cement.

The new data allow us to reconstruct the properties of a sedimentary rock that hosted the ' $S$. cylindrica' nodules. It was composed of clay minerals, relics of which are preserved in the micro-pores between the apatite crystals. It was generally homogeneous but locally contained thin interlayers, enriched with both lighter mineral/organic inclusions and pyrite. The encircled grooves appeared at the intersection of these thin interlayers with the surface of the nodules. The fragments of dendroid graptolites and elongated sponge spicules were located inside this rock, parallel to the thin interlayers, i.e. on the bedding planes.

The only local rock corresponding to the given properties is the lower Tremadocian Dictyonema Shale, which underlies the glauconitic sandstone in most outcrops of the Lower Ordovician of the Baltic-Ladoga Klint. The Dictyonema Shale is homogeneous dark argillite, enriched with organic matter, and interlayered with thin to very thin beds of quartz sand and silt which can be extended or intermittent (Heinsalu 1990, Hints et al. 2014). Scattered pyrite crystals and crystal aggregates are confined to layers of sand and silt, and to layers enriched with organic particles. The small flattened fragments of dendroid graptolites are present in the argillite everywhere. Thin interlayers and lenses of spiculite partially replaced with opal, chalcedony and authigenic quartz, as well as dispersed spicules, are locally distributed in the Dictyonema Shale (Popov et al. 1989, Heinsalu 1990, Loog \& Petersell 1995, Hints et al. 2014).

Questions remain as to how the axial cavities were formed in the phosphorite nodules given that the Dictyonema Shale in the locations of ' $S$. cylindrica' does not have structures that could provide the precursors of these cavities? Such structures, however, are known from other outcrops, where they are represented by vertical burrows of diverse ichnotaxa. The burrows of the ichnogenera Conichnus and Bergaueria are preserved at the top of the Dictyonema Shale at the Syas' River bank (Ershova et al. 2006). Ershova also reported vertical burrows of different depths in the top of the Dictyonema Shale in eight other sections located along the Russian part of the Baltic-Ladoga Klint (Ershova 2008). Deep vertical, taxonomically indeterminate burrows filled with glauconitic sandstone were described from the top of the Dictyonema Shale at Orasoja Brook in Estonia (Heinsalu et al. 2003). The occurrences of the vertical burrows in the top of the Dictyonema Shale, which were formed in shallow waters of the transgressing Baltoscandian Palaeobasin in the early Floian, indicate that in places, and during or slightly preceding the formation of phosphorite nodules, the top of the Dictyonema Mud was penetrated by thin vertical burrows. The term 'Dictyonema Mud' is used here to refer the dewatered lower Tremadocian graptolitebearing, organic-rich mud, which was the precursor of the Dictyonema Shale during the early Floian time. The nodules obviously were formed by crystallization of apatite cements in the mud surrounding more or less extended sections of these burrows. Unmineralized trace fossils completely or partially entombed within phosphorite concretions sometimes occur in the geological record; this kind of mineralization of the host sediment is known as the "collateral preservation" (Hall \& Savdra 2008). After the nodules of 'S. cylindrica' were exhumed 
and re-deposited, parts of the former vertical burrows were preserved as their axial cavities.

The Dictyonema Mud had not yet undergone significant compaction at the time of formation of the nodules but it was sufficiently cohesive. This is evidenced by the 3D-preservation of the graptolite and spicule molds, as well as rounded cross-section of the burrows oriented obliquely or perpendicularly to the axial cavities of the ' $S$. cylindrica' bodies. At present, one can see within the Dictyonema Shale only flattened rhabdosomes of the graptolites, sometimes flattened large acritarchs, such as Lunulidia, which is up to one and a half millimetre long, as well as very rare flattened traces of Planoliteslike ichnofossils. The author's approximate estimate of the degree of post-Floian compaction in the Dictyonema Shale is at least 3-4 times.

As the nodules contain only fragments of trace fossils, reconstruction of the taxonomic composition of infauna that inhabited the obliterated upper layers of the Dictyonema Mud is problematic. The burrows opening to the surface of the Dictyonema Mud, including the axial cavities and 'additional canals' of the ' $S$. cylindrica'nodules, were vertical or near-vertical. Some fragments of the burrows located on the surfaces of the nodules and inside them were oriented obliquely (Figs $2 \mathrm{O}, \mathrm{AC}, \mathrm{AF}, 5 \mathrm{C}, \mathrm{K}, \mathrm{L}$ ) or almost horizontally (Figs $2 \mathrm{M}$, $5 \mathrm{C})$. On the one hand, burrows of different orientations could be attributed to diverse ichnogenera: for example, vertical burrows could represent Skolithos Haldeman, 1840, while oblique and horizontal burrows could record tunnels of Planolites Nicholson, 1873. On the other hand, given the same diameter of all fragments of burrows regardless of their orientation, and following Occam's razor, all these fragments can be interpreted as separated parts of U-shaped burrows belonging to the ichnogenus Arenicolites Salter, 1857.

Whatever ichnogenera these burrows did belong to, burrows were probably not yet filled with glauconitic sandstone during the formation of the nodules; otherwise phosphorite would cement this filling sandstone too.

The funnel-shaped mouths of the axial cavities at the opposite sides of the 'S. cylindrica' nodules (Fig. 2A, F, H, J, K, M, O, Q, T, X, W, AA, AE, AG, AH) cannot be explained solely by the activity of the burrowing infauna. Conical openings have already been shown for Skolithos (e.g. Gaillard \& Racheboeuf 2006, Maceachern et al. 2007) and Arenicolites (e.g. Maceachern et al. 2007, Bradshaw 2010) burrows. More detailed structures of the collar surrounding the pit, as on the nodule enumerated 1/1373 from the Eichwald collection (Fig. 2Q), are also known at the mouths of the Arenicolites burrows (Bradshaw 2010). These openings of the burrows can be used to explain the mouth origin, namely the larger ones, always on only one (upper) side of the nodules.
The reason for the formation of the conical mouth on the opposite (lower) side of the nodules should be sought in the specifics of the nodule growth.

The phosphogenesis that formed the nodules of ' $S$. cylindrica' in the valleys of the Izhora and Popovka rivers, and sandy phosphorite concretions in the Tosna and Sablinka valleys took place during a relatively brief episode against the background of the long transgression of the Hunnberg-Billingen time, which was very slow and sometimes reversed (Nielsen 2011). It is usually believed that the source of phosphorus in the Baltoscandian Palaeobasin during the Middle Ordovician was the Iapetus Ocean, located west of the palaeobasin, and the mechanism for supplying phosphorus to the epeiric sea sediments was coastal upwelling (e.g. Kiipli et al. 2010).

Phosphorite nodules apparently arose as a result of the precipitation of fluorapatite, which fills the interparticle pore space of the Dictyonema Mud around the phosphorusrich nucleation centers inside the near-surface vertical parts of the burrows. Of key importance for the nodule habits was the annular or tubular shape of the nucleation centers, which may be sites primarily enriched with phosphorus compounds as a result of bacterial biofilm activity on the burrow walls or vital/premortal activity of worm-like inhabitants. Judging from the considerable number of the burrows preserved as the 'blind channels' on the surfaces of some nodules, only a negligible number of burrows had centers which could favor phosphoritization. Except for the centers, which were sealed with newly formed apatite microcrystals, the diffuse exchange of pore water of the Dictyonema Mud with the water filling the burrows remained possible. Dilution of a phosphoruscontaining solution by the diffusion process, which reduced concentration of the solution as the distance from the nucleation centres increased along burrow line, could cause the formation of funnel-shaped mouths on the lower (as well as on the upper) side of the nodules.

After the formation of the nodules their surfaces underwent bleaching, which was accompanied by loss of the organic matter and dissolution of opaline spicules inside the nodules. Surface bleaching of phosphorite as indicated by the removal of ferric components and aluminum silicates is an indicator of continental weathering (Altschuler et al. 1957, McArthur \& Walsh 1984). Decomposition and removal of organic matter in phosphorite also indicates the long-term weathering of this rock under continental conditions (McArthur \& Walsh 1984). The result of the removal of the organic matter and easily soluble opal from ' $S$. cylindrica' nodules is the biomorphic voids, replacing graptolites and spicules, and the indefinite voids that probably originated over smaller and softer acritarchs.

Later, when the seawater returned to the locations of the ' $S$. cylindrica', the weathered nodule-containing 
upper layer of the Dictyonema Mud was eroded and the nodules were exhumed and re-deposited in the base of the glauconitic sandstone.

The sandy phosphorite concretions, embedded in the basal layer of glauconitic sandstone in the Tosna and Sablinka rivers, which formed simultaneously with the 'S. cylindrica' nodules, also show the superficial bleaching; however, the sandy concretions were not re-deposited upon the return of sea water. Continental weathering and subsequent marine erosion removed only the uppermost layer of sandstone around the tops of the sandy concretions. Probably, their washing-out was hindered by the moderate cementation of the enclosing sandstone by iron hydroxides formed by pyrite oxidation. It is unlikely that continental weathering lasted more than a hundred years; otherwise the nodules and concretions would have undergone more serious changes.

\section{Conclusions}

(1) Lower Ordovician Siphonia cylindrica Eichwald, 1840 is a pseudofossil and should be excluded from biological databases.

(2) The 'S. cylindrica' nodules consist of microcrystalline phosphorite but not silica, as previously thought.

(3) The 'S. cylindrica' nodules store information on the history of their formation, bleaching and reworking, as well as the primary state and faunal composition of the host rock, so they can be considered as a natural 'recorder' of the erased span of local geological history.

(4) All the events from the nodule formation to their re-deposition occurred in the Prioniodus elegans time interval.

\section{Acknowledgements}

The handling editor Carlton Brett (University of Cincinnati) and Mark A. Wilson (the College of Wooster) are thanked for helpful reviews and comments on the manuscript. This research received no specific grant from any funding agency, commercial or not-for-profit sectors.

\section{References}

Algeo, T.J., Phillips, M., Jaminski, J. \& Fenwick, M. 1994. High-resolution X-radiography of laminated sediment cores. Journal of Sedimentary Research A64, 665-703. DOI 10.1306/D4267E38-2B26-11D7-8648000102C1865D

Alichova, T.N. 1953. The main fauna of brachiopods from the Ordovician of north-western part of Russian platform. 160 pp. Gosgeolizdat, Moscow. [in Russian]

Altschuler, Z.S., Clarke, R.S. \& Yong, E.J. 1957. The Geochemistry of uranium in apatite and phosphorite. USGS Trace Element Investigations Report 701, 1-153.

Asatkin, B.P. 1949. Type Porifera. Sponges, 63-73. In YAnishevskit, M. Z. (ed.) Atlas of the leading forms of the fossil faunas of the USSR, 2. Silurian System. Gosgeolizdat, Moscow. [in Russian]

Bradshaw, M.A. 2010. Devonian Trace Fossils of the Horlick Formation, Ohio Range, Antarctica: Systematic Description and Palaeoenvironmental Interpretation. Ichnos: An International Journal for Plant and Animal Traces 17, 58-114.

Cnudde, V. \& Boone, M.N. 2013. High-resolution X-ray computed tomography in geosciences: a review of the current technology and applications. Earth Science Reviews 123, 1-17. DOI 10.1016/j.earscirev.2013.04.003

Egenhoff, S., Cassle, C., Maletz, J., Frisk, Å.M., Ebbestad, J.O.R. \& Stübner, K. 2010. Sedimentology and sequence stratigraphy of a pronounced Early Ordovician sea-level fall on Baltica - The Bjørkåsholmen Formation in Norway and Sweden. Sedimentary Geology 224, 1-14.

DOI 10.1016/j.sedgeo.2009.12.003

EIchWALD, E. 1840. Ueber das Silurische Schichtensystem in Esthland. Aus dem ersten und zweiten Hefte der "Zeitschrift für Natur-und Heilkunde" der Medizinischen Akademie zu St. Petersburg besonders abgedruckt. 210 pp. St. Petersburg.

EICHWALD, E. 1855. Beitrag zur geographischen Verbreitung der fossilen Thiere Russlands. Alte Periode. Bulletin de la Société Impériale des Naturalistes de Moscou. 28, Premier Partiés, 433-466.

Eichwald, E. 1859. Lethaea Rossica ou Paléontologie de la Russie. Ancienne période. Atlas. 1-8, 59 tabs. Librairie et imprimerie de E. Schweizerbart, Stuttgart.

Eichwald, E. 1860. Lethaea Rossica ou Paléontologie de la Russie. Premier volume. Ancienne période. 1657 pp. Librairie et imprimerie de E. Schweizerbart, Stuttgart.

Eichwald, E. 1861. Paleontology of Russia. Ancient period. Fauna of the Greywacke, Mining-Limestone, and CopperSchist Formations of Russia. 521 pp., 38 tabs. St. Petersburg. [in Russian]

Ershova, V.B. 2008. Condensed deposits of the Varangu and Latorp Regional Stages (Lower Ordovician) of the Russian part of the Baltic-Ladoga Klint. 203 pp. Ph.D. thesis, St. Petersburg State University. St. Petersburg, Russia. [in Russian]

Ershova, V.B., Fedorov, P.V. \& Mikuláš, R. 2006. Trace fossils on and above the transgressive surface: substrate consistency and phosphogenesis (Lower Ordovician, St Petersburg region, Russia). Geologica Carpathica 57, 415-422.

Gaillard, C. \& Racheboeuf, P.R. 2006. Trace fossils from nearshore to offshore environments: Lower Devonian of Bolivia. Journal of Paleontology 80, 1205-1226. DOI 10.1666/0022-3360(2006)80[1205:TFFNTO]2.0.CO;2

GIRTY, G.H. 1927. Geography, geology, and mineral resources of part of southeastern Idaho, with descriptions of Carboniferous and Triassic fossils. USGS Professional Paper 152, 1-451.

Goldfuss, A. 1826-1833. Petrefacta Germaniae: tam ea quae 
in Museo Universitatis Regiae Borussicae Fridericiae Wilhelmiae Rhenanae servantur quam alia quaecunque in Museis Hoeninghusiano Muensteriano aliisque extant; iconibus et descriptionibus illustrate. Abbildungen und Beschreibungen der Petrefacten Deutschlands und der angränzenden Länder, mit Mitwirkung des Herrn Grafen Georg zu Münster. [1826: viii + 1-76; 1829: 77-164; 1831: 165-240; 1833: 241-252]. Arnz \& Co., Düsseldorf.

Haldeman, S.S. 1840. Supplement to number one of "A monograph of the Limniades, and other freshwater univalve shells of North America": containing descriptions of apparently new animals in different classes, and the names and characters of the subgenera in Paludina and Anculosa. 3 pp. J. Dobson, Philadelphia.

Hall, J.T. \& Savdra, C.E. 2008. Ichnofossils and ichnofabrics in syngenetic phosphatic concretions in siliciclastic shelf deposits, Ripley Formation, Cretaceous, Alabama. Palaios 23, 233-245. DOI 10.2110/palo.2006.p06-094r

Heinsalu, H. 1990. Lithology and stratigraphy of the upper Tremadocian graptolite argillite of Northwestern Estonia. Proceedings of Estonian Academy of Sciences. Geology 39, 142-151. [in Russian]

Heinsalu, H. \& BednarczyK, W. 1997. Tremadoc of the East European Platform: Litofacies and Paleogeography. Proceedings of the Estonian Academy of Sciences. Geology 46, 59-74.

Heinsalu, H., Kaljo, D., Kurvits, T. \& Virra, V. 2003. The stratotype of the Orasoja Member (Tremadocian, Northeast Estonia): lithology, mineralogy, and biostratigraphy. Proceedings of Estonian Academy of Sciences. Geology 52, 135-154.

Hints, R., Hade, S., Soesoo, A. \& Voolma, M. 2014. Depositional framework of the East Baltic Tremadocian black shale revisited. Geologiska Föreningens $i$ Stockholm Förhandlingar 136, 464-482.

Kitpli, E., Kitipl, T., Kallaste, T. \& Ainsaar, L. 2010. Distribution of phosphorus in the Middle and Upper Ordovician Baltoscandian carbonate palaeobasin. Estonian Journal of Earth Sciences 59, 247-255. DOI 10.3176/earth.2010.4.01

LAmansky, V.V. 1905. The oldest strata of Silurian deposits in Russia. Transactions of the Geological Committee. New series 20, 1-203. [in Russian, German resume]

Loog, A. \& Petersell, V. 1995. Authigenic siliceous minerals in the Tremadoc graptolitic argillite of Estonia. Proceedings of Estonian Academy of Sciensis. Geology 44, 26-32.

Maceachern, J.A., Pemberton, S.G., Gingras, M.K. \& Bann, K.L. 2007. The ichnofacies paradigm: a fifty-year retrospective, 52-72. In MILLER, III W. (ed.) Trace fossils concepts, problems, prospects. Elsevier, Amsterdam.

MänNIL, R.M. 1966. Evolution of the Baltic Basin during the Ordovician. 200 pp. Valgus, Tallin. [in Russian]

McArthur, J.M. \& Walsh, J.N. 1984. Rare-Earth geochemistry of phosphorites. Chemical Geology 47, 191-220.

DOI 10.1016/0009-2541(84)90126-8

Nicholson, H.A. 1873. Contributions to the study of the errant annelids of the older Palaeozoic rock. Proceedings of the Royal Society of London 21, 288-290.

DOI 10.1098/rspl.1872.0061

Nielsen, A.T. 2011. A re-calibrated revised sea-level curve for the Ordovician of Baltoscandia, 399-401. In GutiérRezMarco, C., Rábano, I. \& García-Bellido, D. (eds) Ordovician of the World. Cuadernos del Museo Geominero, 14. Instituto Geológico y Minero de España, Madrid.

Nielsen, A.T. \& Schovsbo, N.H. 2007. Cambrian to basal Ordovician lithostratigrahy in southern Scandinavia. Bulletin of the Geological Society of Denmark 53, 47-92.

Nikishin, A.M., Ziegler, P.A., Stephenson, R.A., Cloetingh, S.A.P.L., Fume, A.V., Fokin, P.A., Ershov, A.V., Bolotov, S.N., Korotaev, M.V., Alekseev, A.S., Gorbachev, V.I., Shipilov, E.V., Lankreijer, A., Bembinova, E.Yu. \& Shalimov, I.V. 1996. Late Precambrian to Triassic history of the East European Craton: dynamics of sedimentary basin evolution. Tectonophysics 268, 23-63. DOI 10.1016/S0040-1951(96)00228-4

Popov, L.E., Khazanovitch, K.K., Borovko, N.G., Sergeeva, S.P. \& Sobolevskaya, R.F. 1989. The key sections and stratigraphy of the phosphate bearing Obolus beds on the North-East of Russian platform. 222 pp. Nauka, Leningrad. [in Russian]

Ransome, F.L. \& Gale, H.S. 1915. Contributions to economic geology 1913. Part I. Metals and nonmetals except fuels. USGS Bulletin 580, 1-462.

Rhebergen, F. 2012. Ordovizische Spongien aus dem Anstehenden in Estland und der St. Petersburg-Region verglichen mit erratischen Spongien in Deutschland. Geschiebekunde aktuell 28, 1-11.

RõõmusoKs, A. 1960. Ordovician System, 55-113. In OrviKu, K. (ed.) Geology of USSR. 28. Estonian SSR: Geological description and mineral resources. Gosgeoltechizdat, Moscow. [in Russian]

SAlter, J.W. 1857. On annelide burrows and Surface-markings from the Cambrian rocks of the Longmynd. The Quarterly journal of the Geological Society of London 13, 199-206. DOI 10.1144/GSL.JGS.1857.013.01-02.29

Selivanova, V.A. 1971. Ordovician System, 127-173. In Selivanova, V.A. \& Kofman, V.S. (eds) Geology of USSR. I. Leningrad, Pskov, and Novgorod regions: Geological descriptions. Nedra, Moscow. [in Russian]

Sliaupa, S., Forin, P., Lazauskiene, J. \& Stephenson, R.A. 2006. The Vendian-Early Palaeozoic sedimentary basins of the East European Craton. Geological Society, London, Memoirs 32, 449-462.

Sokolova, T.N. 1971. Geological map of the Pre-Quaternary deposits of Leningrad, Pskov, and Novgorod regions. Scale 1:1000000. In Selivanova, V.A. \& Kofman, V.S. (eds) Geology of USSR. I. Leningrad, Pskov, and Novgorod regions: Appendix 1. Nedra, Moscow. [in Russian]

SolLAS, W.J. 1877. On the structure and affinities of the genus Siphonia. Quarterly Journal of the Geological Society of London 33, 790-835. DOI 10.1144/GSL.JGS.1877.033.01-04.46

Suyarkova, A.A. \& Koren', T.N. 2009. Advances in the Ordovician graptolite biostratigraphy of the St. Petersburg area, Russia. Estonian Journal of Earth Sciences 58, 3-9. DOI 10.3176/earth.2009.1.01

Tolmacheva, T.Y. 2001. Conodont biostratigraphy and diversity in the Lower-Middle Ordovician of Eastern Baltoscandia (St. Petersburg region, Russia) and Kazakhstan. 40 pp. 
Comprehensive summary of doctoral dissertation, Uppsala University, Uppsala, Sweden.

Tolmacheva, T.Y., Koren, T.N., Holmer, L.E., Popov, L.E. \& Raevskaya, E. 2001. The Hunneberg Stage (Ordovician) in the area east of St. Petersburg, north-western Russia. Paläontologische Zeitschrift 74, 543-561.

DOI 10.1007/BF02988161
Zander, V.N. \& Salomon, A.P. 1971. Tectonics, 361-407. In Selivanova, V.A. \& Kofman, V.S. (eds) Geology of USSR. I. Leningrad, Pskov, and Novgorod regions: Geological descriptions. Nedra, Moscow. [in Russian]

ZitTEL, K.A. 1878. LIII. Studies on fossil sponges. II. Lithistidae. Annals and Magazine of Natural History: Series 5 2, 467-482. DOI 10.1080/00222937808682397 